\title{
Effects of carrot and tomato juice consumption on faecal markers relevant to colon carcinogenesis in humans
}

\author{
Kerstin Schnäbele ${ }^{1}$, Karlis Briviba ${ }^{2}$, Achim Bub $^{2}$, Silvia Roser ${ }^{1}$, Beatrice L. Pool-Zobel ${ }^{3}$ \\ and Gerhard Rechkemmer ${ }^{1}$ \\ ${ }^{1}$ Chair of the Biofunctionality of Food, Department of Food and Nutrition, Technical University of Munich, Hochfeldweg 1, 85350 \\ Freising, Germany \\ ${ }^{2}$ Institute of Nutritional Physiology, Federal Research Centre for Nutrition and Food, Karlsruhe, Haid-und-Neustraße 9, 76131 \\ Karlsruhe, Germany \\ ${ }^{3}$ Institute for Nutrition, Department of Nutritional Toxicology, Friedrich-Schiller-University, Dornburgerstraße 25, 07743 Jena, \\ Germany
}

(Received 9 February 2007 - Revised 2 July 2007 - Accepted 24 July 2007)

\begin{abstract}
High intakes of carotenoid-rich fruits and vegetables are associated with a reduced risk of various cancers including colon cancer. A human intervention study with carrot and tomato juice should show whether a diet rich in carotenoids, especially high in $\beta$-carotene and lycopene, can modify luminal processes relevant to colon carcinogenesis. In a randomised cross-over trial, twenty-two healthy young men on a low-carotenoid diet consumed $330 \mathrm{ml}$ tomato or carrot juice per $\mathrm{d}$ for 2 weeks. Intervention periods were preceded by 2 -week depletion phases. At the end of each study period, faeces of twelve volunteers were collected for chemical analyses and use in cell-culture systems. Consumption of carrot juice led to a marked increase of $\beta$-carotene and $\alpha$-carotene in faeces and faecal water, as did lycopene after consumption of tomato juice. In the succeeding depletion phases, carotenoid contents in faeces and faecal water returned to their initial values. Faecal water showed high dose-dependent cytotoxic and anti-proliferative effects on colon adenocarcinoma cells (HT29). These effects were not markedly changed by carrot and tomato juice consumption. Neither bile acid concentrations nor activities of the bacterial enzymes $\beta$-glucosidase and $\beta$-glucuronidase in faecal water changed after carrot and tomato juice consumption. Faecal water $\mathrm{pH}$ decreased only after carrot juice consumption. SCFA were probably not responsible for this effect, as SCFA concentrations and profiles did not change significantly. In summary, in the present study, 2-week interventions with carotenoid-rich juices led only to minor changes in investigated luminal biomarkers relevant to colon carcinogenesis.
\end{abstract}

Carotenoids: Tomatoes: Carrots: Juice: Faecal water

Colorectal cancer is one of the most common causes of cancer death in the Western world. Most of the colon tumours are sporadic and develop somatically in epithelial cells ${ }^{1}$. Apart from genetic factors, nutritional factors can markedly affect tumour development. While a high intake of red meat and animal fat is associated with an increased colon cancer risk, epidemiological studies often observed an inverse correlation between a high intake of fruit and vegetables and the incidence of colorectal cancer $^{2-4}$. Protective effects of fruits and vegetables are attributed to ingredients, such as fibres, vitamins and carotenoids. To date, most of the experimental studies about carotenoids investigated the effects of $\beta$-carotene, which often showed anticarcinogenic properties in the colon ${ }^{5-7}$. A number of in vitro studies showed cytotoxic and anti-proliferative effects of $\beta$-carotene on different colon cancer cell lines ${ }^{8-10}$. However, human intervention and epidemiological studies could not clearly verify protective effects of $\beta$-carotene against colon cancer $^{11-15}$. Other carotenoids such as lycopene and lutein have become of more interest in recent research. Epidemiological studies have suggested a decreased colorectal cancer risk with higher tomato consumption ${ }^{16}$, and according to some in vitro studies, lycopene can also inhibit proliferation of human cancer cells ${ }^{17-19}$.

The human colon is continuously exposed to a complex mixture of gut luminal compounds of dietary origin or digestive and microbial processes ${ }^{20}$. These compounds can contribute to colon tumour development by damaging the mucosa, consequently leading to an increased colonic crypt cell proliferation $^{21}$. The analysis of faeces and faecal water therefore represents a useful, non-invasive possibility to assess protective and risk factors of colorectal carcinogenesis. In dietary intervention studies, the cytotoxicity of human faecal water is often used as a biological marker for colon cancer risk $^{22-24}$. Most of these studies focused on bile and fatty acid concentrations in faecal water or its lipid extracts due to the role of fat as a potential tumour promoter in colon carcinogenesis.

Abbreviations: $\mathrm{EC}_{25}$, effective concentration at $25 \%$ reduction of cell viability; $\mathrm{IC}_{50}$, half-maximal growth inhibitory concentration; MTT, 3-[4,5-dimethyl-thiazol -2-yl]-2,5-diphenyltetrazolium bromide.

* Corresponding author: Dr Kerstin Schnäbele, fax +498161 71 2102, email schnaebe@wzw.tum.de 
To our knowledge, no data exist so far about modulations in the composition of faeces and faecal water due to changes in carotenoid intake.

The aim of the present study was to investigate whether a diet rich in carotenoids, especially high in $\beta$-carotene and lycopene, can modify processes relevant to colon carcinogenesis in the gastrointestinal lumen. Therefore, several faecal markers were used in the present study.

\section{Volunteers, materials and methods}

\section{Volunteers and study design}

After screening history and medical examination, twenty-two non-smoking, non-supplement-taking, healthy men (age 28.7 \pm 5.9 years; BMI $23.1 \pm 2.0 \mathrm{~kg} / \mathrm{m}^{2}$ ) were selected for the intervention trial. The study protocol was approved by the medical ethical committee of the Landesärztekammer Baden-Württemberg (Germany). All participants gave their consent in writing, complied with the study protocol and completed both dietary interventions.

The study was designed as a randomised cross-over trial, consisting of two $14 \mathrm{~d}$ interventions with tomato juice or carrot juice (each $330 \mathrm{ml} / \mathrm{d}$; Schoenenberger, Magstadt, Germany). The tomato juice $(330 \mathrm{ml})$ provided $37.0 \mathrm{mg}$ lycopene and $1.6 \mathrm{mg} \beta$-carotene; $330 \mathrm{ml}$ of the carrot juice contained $27.1 \mathrm{mg} \beta$-carotene and $13.1 \mathrm{mg} \alpha$-carotene. Intervention periods were preceded by wash-out phases on a low-carotenoid diet for 2 weeks. After the second intervention period, a third 2week wash-out period succeeded, resulting in a study period of 10 weeks. In an earlier study, we observed that a 2 -week intervention with similar amounts of carrot and tomato juices led to significant increases in plasma concentrations of $\beta$-carotene and lycopene, respectively ${ }^{25}$. Volunteers were told to consume the juices with main meals. Their daily diet was not restricted, but the volunteers were instructed to avoid fruit and vegetables high in carotenoids throughout the whole study (for detailed instructions, see Müller et al. ${ }^{25}$ ). During the last $4 \mathrm{~d}$ of every study phase, the volunteers received an energy- and macronutrient-balanced diet $(51 \pm 2 \%$ energy as carbohydrates, $34 \pm 2 \%$ energy as fat, $15 \pm 1 \%$ energy as protein).

Collection of stool samples was restricted to twelve volunteers (six volunteers per intervention group). Complete $48 \mathrm{~h}$ stool samples were collected during the last $2 \mathrm{~d}$ of every 2 -week period and directly frozen in a freezing toilet at $-40^{\circ} \mathrm{C}$. Samples were stored at $-80^{\circ} \mathrm{C}$ until faecal analyses and the preparation of faecal water, respectively. Every volunteer had at least one defecation during the $2 \mathrm{~d}$ sampling period. The stool weight of the collected faecal samples ( $48 \mathrm{~h}$ stool) was $462 \pm 206 \mathrm{~g}$.

\section{Materials}

Unless otherwise described, all chemicals were purchased from Sigma-Aldrich (Steinheim, Germany). Dulbecco's modified Eagle's medium, penicillin and streptomycin, fetal calf serum and phosphate-buffered saline were obtained from Life Technologies (Eggenstein, Germany). Organic solvents were purchased from Merck (Darmstadt, Germany). Carotenoids for HPLC standard solutions were obtained from Carl Roth (Karlsruhe, Germany).

\section{Cell culture}

The human colon adenocarcinoma cell line HT29 (passages 11-28) was obtained from the German Collection of Microorganisms and Cell Cultures (Braunschweig, Germany). Cells were routinely cultivated in $80 \mathrm{~cm}^{2}$ cell-culture flasks from Nunc (Roskilde, Denmark) in Dulbecco's modified Eagle's medium (with $4.5 \mathrm{~g}$ glucose/l) containing $10 \%(\mathrm{v} / \mathrm{v})$ fetal calf serum, penicillin $\mathrm{G}(50$ units $/ \mathrm{ml})$ and streptomycin $(50 \mu \mathrm{g} / \mathrm{ml})$. Cells were maintained in a humidified atmosphere with $5 \% \mathrm{CO}_{2}$ at $37^{\circ} \mathrm{C}$. Cell-culture medium was replaced three times per week.

\section{Human faecal water preparation}

The frozen faeces samples were thawed and homogenised at $4^{\circ} \mathrm{C}$ (with Stomacher ${ }^{\circledR} 400$; Stomacher ${ }^{\circledR}$ Laboratory Systems, Northampton, UK). The faecal water fraction (the aqueous phase of human faeces) was prepared by ultracentrifugation of a sample of about $100 \mathrm{~g}$ homogenised stool at $60 \cdot 000 \mathrm{~g}$ for $2 \mathrm{~h}$ at $4^{\circ} \mathrm{C}$ (ultracentrifuge Optima ${ }^{\mathrm{TM}} \mathrm{XL}-100 \mathrm{~K}$; Beckmann Coulter, Krefeld, Germany). The supernatant fraction was collected and stored at $-80^{\circ} \mathrm{C}$

To ensure sterile conditions for cytotoxicity and proliferation assays, faecal water was sterile filtered (stepwise filtration through $5,0.65$ and $0.22 \mu \mathrm{m}$ filters, respectively; Millipore GmbH, Eschborn, Germany). Sterile filtered samples were additionally used for the analysis of bile acids and SCFA. Non-filtered faecal water samples served for the determination of carotenoids, $\mathrm{pH}$ and bacterial enzyme activities.

\section{Extraction and analysis of carotenoids}

Samples of homogenised faecal samples $(10 \pm 0 \cdot 1 \mathrm{~g}$, stabilised with $0.22 \%$ butylhydroxytoluene in phosphate-buffered saline) were thawed, diluted with distilled water, and mixed thoroughly. A sample was used for carotenoid extraction with diethyl ether. The organic phase was dried under a stream of $\mathrm{N}_{2}$ gas and dissolved in $100 \mu$ l HPLC mobile phase A (methanol-acetonitrile-2-propanol, 44:52:2 (by vol.), $1 \%$ acetic acid).

Carotenoids were determined by reverse-phase HPLC according to a recently described method ${ }^{10}$.

\section{Cytotoxicity and proliferation assays}

Influences of faecal water on cell viability and proliferation were determined via the 3-[4,5-dimethyl-thiazol-2-yl]-2, 5-diphenyltetrazolium bromide (MTT) assay. MTT is reduced by viable, metabolically active cells to a blue-coloured formazan dye. According to the manufacturer's protocol, cells were incubated with MTT solution $(11 \%(\mathrm{v} / \mathrm{v})$ in cell-culture medium) for $1 \mathrm{~h}$. After cell lysis (buffer with $10 \%$ sodium dodecyl sulfate), the absorbance of the formed formazan was measured at $560 \mathrm{~nm}$ (reference wavelength $690 \mathrm{~nm}$ ) using a microplate reader (SpectraFluor Plus; Tecan Deutschland $\mathrm{GmbH}$, Crailsheim, Germany).

For cytotoxicity assays, HT29 cells were seeded into ninetysix-well cell-culture plates (60.000 cells/well) and grown until they reached confluence. Subsequently, cells were incubated 
for $24 \mathrm{~h}$ with faecal water samples used in the following concentrations: $10,5,2 \cdot 5,2$ and $1 \%(\mathrm{v} / \mathrm{v})$ in cell-culture medium (see Fig. 2 (A)).

For proliferation assays, cells were seeded into ninety-sixwell cell-culture plates (5000/well) and incubated with cellculture medium overnight to allow cells to attach to the plate before treatment. After removing the medium, cells were incubated with faecal water in a concentration of 10 , $5,2,1$ and $0.5 \%$ in cell-culture medium. Cell proliferation was measured after 1,2 and $5 \mathrm{~d}$ of treatment using the MTT test as described earlier. A typical dose-dependent effect of a volunteer's faecal water samples on cell proliferation is shown in Fig. 2 (B).

\section{Extraction, derivatisation and measurement of bile acids}

Conjugated bile acids in faecal water samples $(100 \mu \mathrm{l})$ were hydrolysed for $2 \mathrm{~h}$ at $80^{\circ} \mathrm{C}$ in $1 \mathrm{ml} 1 \mathrm{M}$-alkaline methanol $(80 \%)$. After addition of $100 \mu \mathrm{l} \mathrm{HCl}(32 \%$, v/v) and evaporation to dryness under a stream of $\mathrm{N}_{2}$ gas, the samples were dissolved in $5 \mathrm{ml} 0 \cdot 1 \mathrm{M}$-phosphate buffer $(\mathrm{pH} \mathrm{7 \cdot 0)}$. The samples were purified using Oasis HLB-cartridges (30 mg; Waters, Milford, MA, USA) that were preconditioned with $2 \mathrm{ml}$ methanol and $5 \mathrm{ml}$ phosphate buffer. After washing with $2 \mathrm{ml}$ buffer, bile acids were eluted with $4 \mathrm{ml}$ methanol. Then $150 \mu 11.8 \mathrm{mM}-\mathrm{KOH}$-methanol were added to the dried eluates and samples were evaporated again at $80^{\circ} \mathrm{C}$ under a stream of $\mathrm{N}_{2}$ gas and stored overnight at $-20^{\circ} \mathrm{C}$ before derivatisation.

The derivatisation procedure and HPLC analysis of bile acids were performed as reported by Guldutuna et al. with some modifications ${ }^{26}$. The prepared samples were incubated with $50 \mu \mathrm{l}$ dicyclohexyl-18-crown-6-ether $(5 \mathrm{mmol} / \mathrm{l}$ dissolved in acetonitrile) and $50 \mu \mathrm{l}$ of the fluorescent substance 4-bromomethyl-7-methoxycoumarin $(5 \mathrm{mM}$ in acetonitrile) for $1 \mathrm{~h}$ at $37^{\circ} \mathrm{C}$. After cooling down for $10 \mathrm{~min}$ on ice and centrifugation at $800 \mathrm{~g}$ for $3 \mathrm{~min}, 20 \mu \mathrm{l}$ of the samples were injected.

Separation was carried out with a water-acetonitrile (60:40, v/v) mobile phase A and an acetonitrile-methanol-butanol (47:23:30, by vol.) mobile phase $\mathrm{B}$ at a constant flow rate of $1 \mathrm{ml} / \mathrm{min}$ using a $\mathrm{C}_{18}$ column $(5 \mu \mathrm{m} ; 250 \times 4.6 \mathrm{~mm}$; Vydac, Hesperia, CA, USA). Gradient elution was started with $80 \%$ $\mathrm{A}$ and was performed by changing the mobile phase $\mathrm{B}$ to $100 \%(0-5 \mathrm{~min} 20 \% \mathrm{~B}, 5-15 \mathrm{~min}$ to $25 \% \mathrm{~B}, 15-25 \mathrm{~min}$ to $30 \% \mathrm{~B}, 25-30 \mathrm{~min} 30 \% \mathrm{~B}, 30-35 \mathrm{~min}$ to $50 \% \mathrm{~B}$, $35-36 \mathrm{~min} 50 \% \mathrm{~B}, 36-40 \mathrm{~min}$ to $60 \% \mathrm{~B}, 40-41 \mathrm{~min}$ to $70 \% \mathrm{~B}, 41-45 \mathrm{~min}$ to $80 \% \mathrm{~B}, 45-55 \mathrm{~min}$ to $100 \% \mathrm{~B})$. Bile acids were determined with a fluorescence detector (Shimadzu model RF-535, Shimadzu, Duisburg, Germany; excitation at $340 \mathrm{~nm}$, emission at $410 \mathrm{~nm}$ ) and a chromatointegrator (Merck-Hitachi model D-2500; Merck-Hitachi Ltd., Tokyo, Japan). Peaks of cholic acid, chenodeoxycholic acid, deoxycholic acid, lithocholic acid, and ursodeoxycholic acid were identified based on relative retention times and by comparison with those of pure standard mixtures.

\section{Measurement of short-chain fatty acids}

SCFA were analysed by GC (HP5890II with automatic injector HP7673 II; Hewlett-Packard, Böblingen, Germany). Samples were deproteinated with $10 \%$ formic acid. After high-speed centrifugation, the SCFA acetate, propionate and butyrate were separated isothermally on chromosorb WAW (80/100 mesh) with $20 \%$ neopentenylglucosinolate and $2 \%$ phosphoric acid. Operation conditions were: injection temperature $130^{\circ} \mathrm{C}$, carrier flow of $\mathrm{N}_{2}$ gas $25 \mathrm{ml} / \mathrm{min}$, column oven temperature $130^{\circ} \mathrm{C}$, temperature of the flame ionisation detector $250^{\circ} \mathrm{C}$.

\section{Activities of the bacterial enzymes $\beta$-glucosidase and $\beta$-glucuronidase}

Bacterial enzyme acitivities were assayed in duplicate by a method of Hylla et $a ._{.}{ }^{27}$ with some modifications. The $\beta$-glucosidase reaction was run at $37^{\circ} \mathrm{C}$ in a total volume of $1 \mathrm{ml}$ consisting of $100 \mu \mathrm{l} 1: 10$ diluted faecal water, $100 \mu \mathrm{l} 0 \cdot 01$ M-p-nitrophenyl glucoside and $800 \mu \mathrm{l}$ actetate buffer $(0.1 \mathrm{~mol} / \mathrm{l} ; \mathrm{pH} 4 \cdot 5)$. The reaction was stopped after $0,15,30$, 45,60 and $75 \mathrm{~min}$ of incubation by adding $500 \mu \mathrm{l}$ of a $1: 1$ mixture of glycine buffer $(0.3 \mathrm{~mol} / \mathrm{l} ; \mathrm{pH} 10 \cdot 4)$ and distilled water. The $p$-nitrophenyl released was measured photometrically at $400 \mathrm{~nm}$.

$\beta$-Glucuronidase was determined under similar conditions by using $100 \mu \mathrm{l} \quad 0.01 \quad$ M-phenolphthalein- $\beta$-D-glucuronide, $400 \mu \mathrm{l}$ 1:5 diluted faecal water and $400 \mu \mathrm{l}$ acetate buffer. The release of phenolphthalein was measured at $552 \mathrm{~nm}$. The enzyme activities were calculated within the linear reaction range by using standard curves for the corresponding substrates. They are expressed as mg liberated substrate per $h$ and per $\mathrm{ml}$ faecal water.

\section{Statistical methods}

In order to simplify the comparison of dose-dependent cytotoxic or anti-proliferative effects of faecal water preparations from intervention periods and the preceding depletion phases, we calculated non-linear regression curves as represented in Fig. 2 using SigmaPlot version 4.01 from SPSS Science Software (Erkrath, Germany). According to the measurement range of cell assays, we used calculated effective concentrations at $25 \%$ reduction of cell viability $\left(\mathrm{EC}_{25}\right)$ or half-maximal growth inhibitory concentrations $\left(\mathrm{IC}_{50}\right)$ from non-linear regression for the following statistical analyses.

All measured parameters were first tested for potential intervention, period or carry-over effects via cross-over design analyses (various $t$ tests) using NCSS 97 (NCSS Systems, Kaysville, UT, USA). If period or carry-over effects could not be observed, data of both subject groups of the cross-over intervention trial (group 1, tomato then carrot juice, group 2, carrot then tomato juice) were merged. Paired Student's $t$ tests served for analysis of intervention effects from carrot and tomato juice consumption (before $v$. after each juice consumption). These statistical calculations and correlations between different parameters were performed with SigmaStat ${ }^{\circledR} \quad 3.0$ (SPSS Science Software). Significance level was set at $P \leq 0.05$. If the measured data were not normally distributed, equivalent non-parametric statistical tests were used.

As faecal material was limited, unfortunately we could not perform all analyses with every sample. Therefore, the number of investigated volunteer samples is always shown subsequently. 
Inter-assay $\mathrm{CV}$ for the analytical carotenoid, bile acid and SCFA measurements described earlier were below $10 \%$.

\section{Results}

Carrot juice supplementation $(330 \mathrm{ml} / \mathrm{d})$ for 2 weeks significantly increased faecal contents of $\beta$ - and $\alpha$-carotene (Fig. 1). Lycopene amounts were elevated after tomato juice $(330 \mathrm{ml} / \mathrm{d})$ consumption. After the following wash-out period, concentrations of these carotenoids in faeces decreased to initial values (Fig. 1).

Carotenoid concentrations in non-filtered faecal water - analysed from $500 \mu \mathrm{l}$ faecal water samples of four volunteers - were also elevated after consumption of both juices. For example, $\beta$-carotene concentration was increased from $0 \cdot 2$ (SD $0 \cdot 2) \mu \mathrm{mol} / \mathrm{l}$ before to $49 \cdot 2$ (SD $16 \cdot 6) \mu \mathrm{mol} / \mathrm{l}$ after carrot juice consumption. Lycopene concentrations averaged 0.7 (SD 1.5) $\mu \mathrm{mol} / \mathrm{l}$ before and reached $83 \cdot 1$ (SD 50.0) $\mu \mathrm{mol} / \mathrm{l}$ after tomato juice consumption. Carotenoid concentrations in the sterile filtered faecal water samples were below the detection limit.

Whereas stool weight did not change during the whole study, water content of faecal samples was significantly reduced by $4 \%$ after carrot juice consumption in the first intervention period (Table 1). Additionally, a mean reduction of 0.38 in faecal water $\mathrm{pH}$ was observed after carrot juice consumption.

In cell-culture experiments, viability of confluent HT29 cells was always markedly reduced in a concentrationdependent manner after $24 \mathrm{~h}$ treatment with faecal water (Fig. 2 (A)). For comparison of cytotoxic effects from the different faecal water samples, we used calculated concentrations causing $25 \%$ reduction in cell viability $\left(\mathrm{EC}_{25}\right.$ values; Table 2). Carrot juice consumption did not cause a change in faecal water cytotoxicity. In contrast, $\mathrm{EC}_{25}$

A

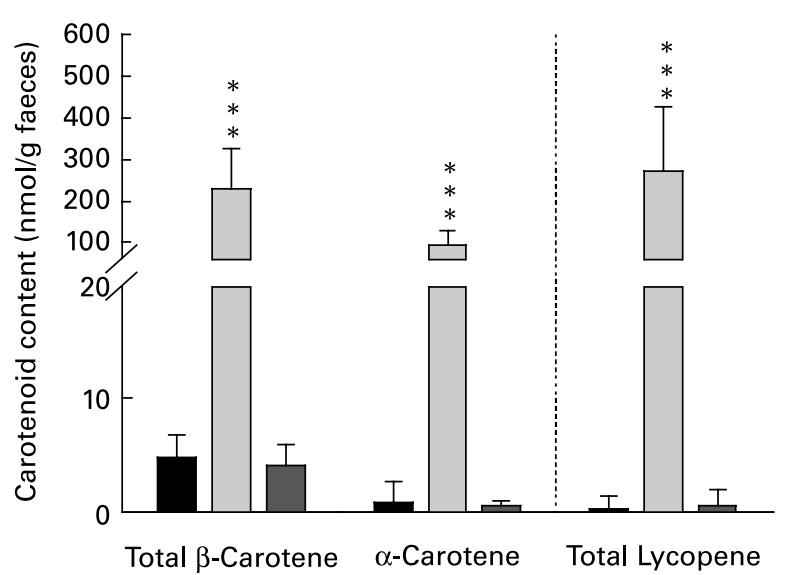

Fig. 1. Faecal content of carotenoids after 2-week periods of depletion preceding ( $\square$ ) and succeeding ( $\square$ ) carrot (A) and tomato (B) juice intervention (ם). Carotenoids in faeces were determined including all-trans and cis configurations. No differences between the two intervention groups of the crossover trial were observed in any intervention period $(P \geq 0.37)$, indicating that the sequence of juice consumption had no effect on carotenoid excretion. Therefore, data of faecal carotenoid amounts of both intervention groups were merged. Values are means from all volunteers ( $n 12$ per study phase) with standard deviations represented by vertical bars. ${ }^{* * *}$ Mean value was significantly different from those preceding and succeeding the juice intervention $(P \leq 0.001)$ values were increased on average by $1.1 \%$ after tomato juice consumption. However, this reduction in cytotoxicity seemed to be negligible, as it was in the intra-individual range of the test system.

A strong dose-dependent inhibition of cell growth was observed after $5 \mathrm{~d}$ treatment of proliferating HT29 cells (Fig. 2 (B)). This incubation time was used for calculation of half-maximal inhibitory concentrations ( $\mathrm{IC}_{50}$ values; Table 2). Neither tomato nor carrot juice consumption affected the anti-proliferative properties of faecal water.

Further markers in faecal water that could not markedly be modified by juice consumption were the activities of the two bacterial enzymes $\beta$-glucosidase and $\beta$-glucuronidase (Table 2 ), as well as the concentrations of bile acids and SCFA (Table 3 ).

\section{Discussion}

Several epidemiological studies have provided compelling evidence that a high intake of vegetables and fruits rich in carotenoids decreases the risk for many types of cancer including colorectal cancer ${ }^{2,4,16,28}$. Franceschi et al. ${ }^{28}$ proposed a reduced risk of colorectal cancer of more than $20 \%$ after one additional daily serving of most vegetables including carrots and tomatoes. Cancer-related molecular mechanisms of carotenoids such as cytotoxic, anti-proliferative and apoptosis-inducing effects have been identified in vitro ${ }^{8-10,17}$. Whether carotenoids can modulate these mechanisms in vivo, especially in the presence of other bioactive compounds within a complex food matrix, is not yet clear.

In the present study, HPLC analysis showed that consumption of carrot and tomato juices caused an increase in the amounts of $\beta$-carotene and lycopene in faeces and faecal water. Stepwise filtration showed that carotenoids in faecal water are present in structures with a diameter size ranging between 0.65 and $5.0 \mu \mathrm{m}$. HT29 cells can take up carotenoids from emulsions with particles sized between $0 \cdot 3$ and $1.0 \mu \mathrm{m}^{29}$. In carrots and tomatoes, $\beta$-carotene and lycopene, respectively, occur as membrane-bound semi-crystalline structures derived from plastids ${ }^{30}$. The release of carotenoids from the food matrix is a key step in their bioavailability. Goni et al. ${ }^{31}$ demonstrated by an in vitro gastrointestinal digestion model that carotenoids can be released from the food matrix by bacterial enzyme activity and assumed that $\beta$-carotene was potentially available for absorption in the colon, because it was not utilised as substrate during in vitro colonic fermentation. To our present knowledge, it is unknown in which form carotenoids (associated to indigestible food residues, as precipitated crystals, or incorporated into micelles) occur in faecal water and if they could at least in part be taken up by colonocytes.

Gut luminal compounds, especially free reactive and soluble substances, can contribute to colon tumour development $^{32}$. In the present study, the investigations of filtered faecal water should show potential indirect effects of a carotenoid-rich diet on faecal water composition and its impact on the cell-culture model system HT29. Particularly, nonabsorbed water-soluble compounds present in vegetable juices or produced by the intestinal microflora as a consequence of dietary changes could be of importance. HT29 treatment with non-filtered faecal water should provide additional 
Table 1. General markers of faecal samples from the intervention trial

(Mean values and standard deviations and number of tested volunteers per intervention group)

\begin{tabular}{|c|c|c|c|c|c|c|c|c|c|}
\hline \multirow{3}{*}{$\begin{array}{l}\text { Intervention... } \\
\text { Marker }\end{array}$} & \multicolumn{4}{|c|}{ Carrot juice } & \multicolumn{4}{|c|}{ Tomato juice } & \multirow[b]{3}{*}{$n$} \\
\hline & \multicolumn{2}{|c|}{$\begin{array}{c}\text { Before } \\
\text { consumption }\end{array}$} & \multicolumn{2}{|c|}{$\begin{array}{c}\text { After } \\
\text { consumption }\end{array}$} & \multicolumn{2}{|c|}{$\begin{array}{c}\text { Before } \\
\text { consumption }\end{array}$} & \multicolumn{2}{|c|}{$\begin{array}{c}\text { After } \\
\text { consumption }\end{array}$} & \\
\hline & Mean & SD & Mean & SD & Mean & SD & Mean & SD & \\
\hline Water & 78 & 6 & $74^{*}$ & 4 & 73 & 5 & 78 & 4 & $6 \dagger$ \\
\hline Faecal water $\mathrm{pH}$ & 6.73 & 0.45 & $6 \cdot 34^{*}$ & 0.42 & 6.76 & 0.47 & 6.67 & 0.41 & 12 \\
\hline
\end{tabular}

* Mean value was significantly different from that before juice consumption $(P \leq 0.05)$.

t Carry-over effects $(P=0.4)$ were observed during the statistical cross-over design analyses. Therefore, only the first $14 \mathrm{~d}$ treatments of the two volunteer groups were included in the analysis of intervention effects from carrot and tomato juice consumption.

information about direct carotenoid effects on the colonic epithelium in the presence of other luminal compounds.

In line with previous studies ${ }^{33}$, filtered faecal water samples from our intervention trial showed pronounced cytotoxic effects on confluent HT29 cells. Cytotoxicity, however, was not modified by carrot or tomato juice consumption (Table 2) and it was independent from dilution effects (correlation with water amount in faeces: $r-0 \cdot 04 ; P=0 \cdot 77)$. Non-filtered faecal water samples exceeded carotenoid levels that had cytotoxic potential in our previous study ${ }^{10}(30 \mu \mathrm{mol} / \mathrm{l})$ and showed stronger cytotoxic effects than filtered ones, but their cytotoxicity was not affected by carrot and tomato juice consumption.

Although we observed strong anti-proliferative effects of isolated $\beta$-carotene ( $\mathrm{IC}_{50}: 11-16 \mu \mathrm{mol} / 1$ after $5 \mathrm{~d}$ treatment) in a previous study ${ }^{10}$, we could not detect modifications in anti-proliferative effects of non-filtered faecal water after carrot and tomato juice consumption (data not shown). An explanation for the lack of effects of the juice interventions might be the high cytotoxic and anti-proliferative potential of faecal water. Even samples containing low or non-detectable amounts of carotenoids (for example, samples from washout phases or filtered samples) had to be diluted for cytotoxicity and proliferation measurements. For example, to reach $\mathrm{IC}_{50}$, faecal water had at least to be diluted about 100 -fold (see Table 2). Therefore, it was not possible to detect potential but low carotenoid effects in our test system. Other luminal compounds seem to be more active.

Bile acids are considered to contribute to colon carcinogenesis by disturbing the balance between proliferation, differentiation and apoptosis in colonic cells ${ }^{33}$. In vitro, lithocholic acid, chenodeoxycholic acid and deoxycholic acid showed cytotoxic effects on human colon tumour cell lines, including HT $29^{34}$. In the present study, concentrations of bile acids in faecal water did not change significantly after carrot or tomato juice consumption (Table 3). Total concentration of bile acids measured in faecal water was with maximal $33.6 \mu \mathrm{mol} / \mathrm{l}$ considerably below effective $\mathrm{IC}_{50}$ bile acid concentrations for HT29 cells ${ }^{34}$. This does not indicate direct bile acid effects on faecal water cytotoxicity in our test system.

A low faecal $\mathrm{pH}$ has been associated with a decreased incidence of colon cancer ${ }^{35}$. For instance, changes in the composition of the gut flora and the bacterial production of potentially cancer-protective SCFA are linked to this observation. We observed a marked decrease in faecal water $\mathrm{pH}$
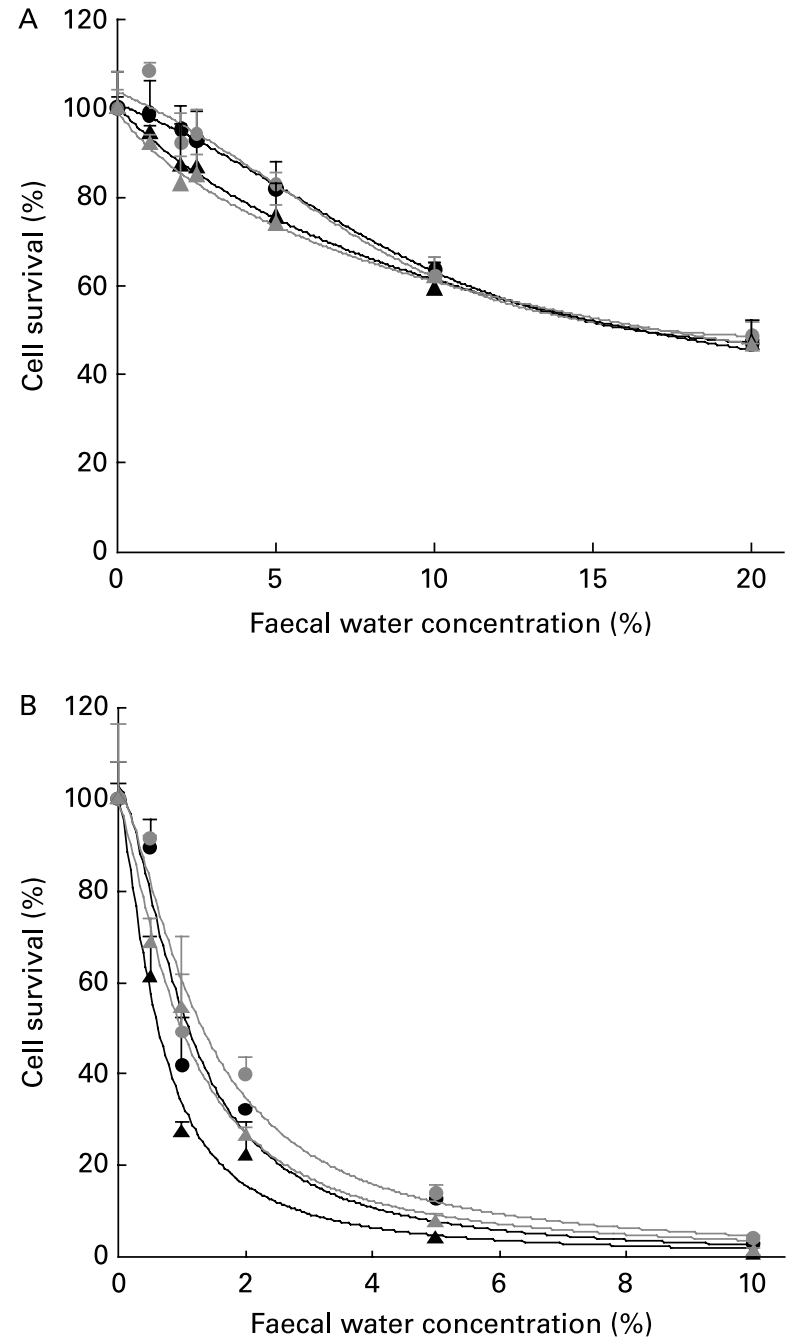

Fig. 2. Dose-dependent cytotoxic (A) and anti-proliferative (B) effects of faecal water samples (non-linear regression curves) from one volunteer on HT29 cells. (A) Cytotoxicity was assessed by the 3-[4,5-dimethyl-thiazol2-yl]-2,5-diphenyltetrazolium bromide (MTT) test after $24 \mathrm{~h}$ treatment. (B) Growth inhibition effects were measured via MTT after $5 \mathrm{~d}$ of treatment. Values are the means of one experiment with triplicate determination and are related to the untreated control, which was set at $100 \%$, with standard deviations represented by vertical bars. Samples are: $(\bullet)$, before carrot juice consumption; (๑), after carrot juice consumption; $(\mathbf{\Lambda})$, before tomato juice consumption; ( $\Delta)$, after tomato juice consumption. 
Table 2. Biological effects of faecal water depending on the study phase

(Mean values and standard deviations and number of tested volunteers per intervention group)

\begin{tabular}{|c|c|c|c|c|c|c|c|c|c|}
\hline \multirow{3}{*}{$\begin{array}{l}\text { Intervention... } \\
\text { Marker }\end{array}$} & \multicolumn{4}{|c|}{ Carrot juice } & \multicolumn{4}{|c|}{ Tomato juice } & \multirow[b]{3}{*}{$n$} \\
\hline & \multicolumn{2}{|c|}{$\begin{array}{c}\text { Before } \\
\text { consumption }\end{array}$} & \multicolumn{2}{|c|}{$\begin{array}{c}\text { After } \\
\text { consumption }\end{array}$} & \multicolumn{2}{|c|}{$\begin{array}{c}\text { Before } \\
\text { consumption }\end{array}$} & \multicolumn{2}{|c|}{$\begin{array}{c}\text { After } \\
\text { consumption }\end{array}$} & \\
\hline & Mean & SD & Mean & SD & Mean & SD & Mean & SD & \\
\hline Cytotoxicity: $\mathrm{EC}_{25}$ values (\%)† & $6 \cdot 8$ & $2 \cdot 7$ & $7 \cdot 7$ & 1.5 & $4 \cdot 8$ & $1 \cdot 7$ & $5 \cdot 9^{\star}$ & $1 \cdot 1$ & $6 \neq$ \\
\hline Growth inhibition: $I C_{50}$ values $(\%) \S$ & 0.8 & $0 \cdot 2$ & 0.9 & $0 \cdot 3$ & $1 \cdot 1$ & 0.5 & $1 \cdot 0$ & 0.6 & 7 \\
\hline Activity of bacterial $\beta$-glucuronidase (mg substrate $/ \mathrm{h} \times \mathrm{ml}$ ) & 0.5 & 0.6 & 0.5 & 0.3 & 0.3 & 0.2 & 0.4 & 0.3 & 6 \\
\hline
\end{tabular}

* Mean value was significantly different from that before juice consumption $(P \leq 0.05)$.

$+\mathrm{EC}_{25}$ values were calculated by non-linear regression and represent the effective concentrations of faecal water samples in cell-culture medium that lead to a $25 \%$ reduction of HT29 cell viability compared with the untreated control after $24 \mathrm{~h}$ treatment.

$\ddagger$ Period effects $(P=0.02)$ were observed during the statistical cross-over design analyses. Therefore, only the first $14 \mathrm{~d}$ periods of the two intervention groups were included in the analysis of effects from carrot and tomato juice consumption.

$\S \mathrm{IC}_{50}$ values were calculated by non-linear regression and represent the inhibition concentrations of faecal water samples indicating a $50 \%$ reduction of $\mathrm{HT} 29$ cell growth compared with the untreated control after $5 \mathrm{~d}$ treatment.

after carrot juice consumption. Whether this effect was due to an increased biochemical activity of the microflora or changes in the flora composition should be investigated in further studies. The intake of dietary fibre increased by an average of 7.9 and $8.6 \%$ by carrot and tomato juice consumption, respectively (data not shown). Differences between the effects of carrot and tomato juice intervention could be caused by variations in the composition of dietary fibre or differences in the juice matrices which could influence the sites of colonic fermentation.

The major colonic SCFA acetate, propionate and butyrate that play a central role in colon homeostasis ${ }^{36}$ could not have been exclusively responsible for the observed decrease in faecal water $\mathrm{pH}$. Their concentrations in faecal water did not change significantly after carrot juice consumption (and also not after tomato juice consumption). Perhaps SCFA contributed to an increased resorption of water in the distal colon and therefore to the observed decrease in water content of faecal samples after carrot juice consumption (Table 1).

Some bacterial enzymes of the gut flora including $\beta$-glucuronidase and $\beta$-glucosidase are associated with the generation of potentially carcinogenic metabolites in the colon ${ }^{37}$. In the present study, the activities of $\beta$-glucuronidase and $\beta$-glucosidase were in the range described in earlier studies ${ }^{27,38}$, but were not significantly modified by carrot and tomato juice consumption (Table 2).

We cannot completely exclude the lack of effects due to the limited number of data. To increase the yield of faecal water in future studies, we recommend the modification of the faecal water preparation method, for example, dilution of faecal samples with buffer before centrifugation and use of filters with a larger diameter.

Although in vitro experiments with cancer cells have their limitations, they provide important information on molecular

Table 3. Exposition markers of faecal water depending on subject treatment (Mean values and standard deviations of eight volunteers per intervention group)

\begin{tabular}{|c|c|c|c|c|c|c|c|c|}
\hline \multirow{3}{*}{$\begin{array}{l}\text { Intervention... } \\
\text { Compound }\end{array}$} & \multicolumn{4}{|c|}{ Carrot juice } & \multicolumn{4}{|c|}{ Tomato juice } \\
\hline & \multicolumn{2}{|c|}{$\begin{array}{c}\text { Before } \\
\text { consumption }\end{array}$} & \multicolumn{2}{|c|}{$\begin{array}{c}\text { After } \\
\text { consumption }\end{array}$} & \multicolumn{2}{|c|}{$\begin{array}{c}\text { Before } \\
\text { consumption }\end{array}$} & \multicolumn{2}{|c|}{$\begin{array}{c}\text { After } \\
\text { consumption }\end{array}$} \\
\hline & Mean & SD & Mean & SD & Mean & SD & Mean & SD \\
\hline \multicolumn{9}{|l|}{ Bile acids $(\mu \mathrm{mol} / \mathrm{l})$} \\
\hline $\mathrm{CA}$ & 1.8 & 1.0 & $1 \cdot 2$ & 0.7 & 1.8 & 1.4 & $2 \cdot 2$ & 1.9 \\
\hline CDCA & 1.0 & 0.5 & 0.9 & 0.6 & 0.9 & 0.7 & 1.3 & 1.0 \\
\hline DCA & 5.8 & 6.5 & 3.4 & $2 \cdot 3$ & $6 \cdot 2$ & 4.4 & $5 \cdot 2$ & 3.3 \\
\hline LCA & $1 \cdot 1$ & 0.7 & 1.3 & 0.9 & 1.4 & 0.7 & 1.8 & $1 \cdot 2$ \\
\hline UCA & $2 \cdot 7$ & $2 \cdot 1$ & 1.8 & 0.6 & $3 \cdot 0$ & $2 \cdot 4$ & 3.9 & 3.6 \\
\hline Total bile acids & $12 \cdot 4$ & 8.9 & 8.6 & 3.3 & $13 \cdot 3$ & $7 \cdot 0$ & 14.5 & 8.7 \\
\hline \multicolumn{9}{|l|}{ SCFA $(\mathrm{mmol} / \mathrm{l})$} \\
\hline Acetate & 75.5 & $20 \cdot 4$ & 76.8 & $22 \cdot 6$ & 68.8 & $21 \cdot 8$ & $70 \cdot 1$ & 23.3 \\
\hline Butyrate & $27 \cdot 1$ & 11.3 & 28.5 & 11.8 & 23.5 & 11.3 & $23 \cdot 3$ & 8.9 \\
\hline Propionate & $22 \cdot 4$ & $10 \cdot 3$ & $18 \cdot 6$ & $6 \cdot 7$ & 21.9 & $9 \cdot 1$ & $18 \cdot 3^{*} \dagger$ & 8.5 \\
\hline Total SCFA & 124.9 & 34.5 & 123.9 & 36.5 & $114 \cdot 2$ & $35 \cdot 0$ & 111.7 & 31.1 \\
\hline
\end{tabular}

CA, cholic acid; CDCA, chenodeoxycholic acid; DCA, deoxycholic acid; LCA, lithocholic acid; UCA, ursodeoxycholic acid. ${ }^{*}$ Mean value was significantly different from that before juice consumption $(P \leq 0.05)$.

$\dagger$ The reduction of propionate in faecal water after tomato juice consumption seemed to be negligible, as it was in the intra-individual concentration range of the depletion phases of the whole study. 
mechanisms. We selected HT29 cancer cells for our cell-culture test system, as permanent normal human colonic cell lines are not available at present. HT29 cells are well characterised, showed low variance in our earlier experiments and are often used for investigations about the influence of luminal contents on colon carcinogenesis ${ }^{24,32,39}$. Subsequently, conducting a human intervention study that includes the investigation of colonic biopsy material would be of great interest, even though taking biopsies represents an invasive method and also has methodological problems.

In summary, although consumption of both carotenoid-rich juices for 2 weeks increased the carotenoid level in faeces, no changes in the cytotoxic and anti-proliferative properties of faecal water, in the bile and SCFA concentrations, as well as bacterial enzyme activities in faecal water, were observed. This indicates that other anticarcinogenic mechanisms of carrots and tomatoes seem to be of greater importance. Further intervention studies focusing on other markers related to cancer prevention such as protection from DNA damage, induction of phase II enzymes and changes in inflammation markers are required.

\section{Acknowledgements}

The present study was supported by a grant from the 'Deutsche Krebshilfe' (project no. 70-2165). The authors thank C. Driesner, S. Demirel and C. Hodapp for their excellent technical assistance, L. Korn for his statistical consultation and the volunteers for taking part in the present study. The authors also thank Mrs Becker from the Institute of Physiology, University of Veterinary Medicine Hannover, Germany for the GC analyses of SCFA. Carrot and tomato juice were kindly provided by Schoenenberger Pflanzensaefte, Magstadt, Germany.

\section{References}

1. Ilyas M, Straub J, Tomlinson IP \& Bodmer WF (1999) Genetic pathways in colorectal and other cancers. Eur J Cancer 35, 335-351.

2. Potter JD, Slattery ML, Bostick RM \& Gapstur SM (1993) Colon cancer: a review of the epidemiology. Epidemiol Rev 15, 499-545

3. World Cancer Research Fund (1997) Food, Nutrition and the Prevention of Cancer: a Global Perspective. Washington, DC: World Cancer Research Fund and American Institute for Cancer Research.

4. Riboli E \& Norat T (2003) Epidemiologic evidence of the protective effect of fruit and vegetables on cancer risk. Am J Clin Nutr 78, Suppl. 3, 559S-569S.

5. Krinsky NI (1991) Effects of carotenoids in cellular and animal systems. Am J Clin Nutr 53, Suppl. 1, 238S-246S.

6. Alabaster O, Tang Z, Frost A \& Shivapurkar N (1995) Effect of $\beta$-carotene and wheat bran fibre on colonic aberrant crypt and tumour formation in rats exposed to azoxymethane and high dietary fat. Carcinogenesis 16, 127-132.

7. Komaki C, Okuno M, Onogi N, Moriwaki H, Kawamori T, Tanaka T, Mori H \& Muto Y (1996) Synergistic suppression of azoxymethane-induced foci of colonic aberrant crypts by the combination of $\beta$-carotene and perilla oil in rats. Carcinogenesis 17, 1897-1901.
8. Iftikhar S, Lietz H, Mobarhan S \& Frommel TO (1996) In vitro $\beta$-carotene toxicity for human colon cancer cells. Nutr Cancer 25, 221-230.

9. Onogi N, Okuno M, Matsushima-Nishiwaki R, Fukutomi Y, Moriwaki H, Muto Y \& Kojima S (1998) Antiproliferative effect of carotenoids on human colon cancer cells without conversion to retinoic acid. Nutr Cancer 32, 20-24.

10. Briviba K, Schnäbele K, Schwertle E, Blockhaus M \& Rechkemmer G (2001) $\beta$-Carotene inhibits growth of human colon carcinoma cells in vitro by induction of apoptosis. Biol Chem 382, 1663-1668.

11. van Poppel G \& Goldbohm RA (1995) Epidemiologic evidence for $\beta$-carotene and cancer prevention. Am J Clin Nutr 62, 1393S-1402S.

12. Greenberg ER, Baron JA, Tosteson TD, Freeman DH Jr, Beck GJ, Bond JH, Colacchio TA, Coller JA, Frankl HD \& Haile RW (1994) A clinical trial of antioxidant vitamins to prevent colorectal adenoma. Polyp Prevention Study Group. $N$ Engl $J$ Med 331, 141-147.

13. The Alpha-Tocopherol, Beta Carotene Cancer Prevention Study Group (1994) The effect of vitamin $E$ and $\beta$ carotene on the incidence of lung cancer and other cancers in male smokers. $N$ Engl J Med 330, 1029-1035.

14. Albanes D, Malila N, Taylor PR, et al. (2000) Effects of supplemental $\alpha$-tocopherol and $\beta$-carotene on colorectal cancer: results from a controlled trial (Finland). Cancer Causes Control 11, 197-205.

15. Baron JA, Cole BF, Mott L, Haile R, Grau M, Church TR, Beck GJ \& Greenberg ER (2003) Neoplastic and antineoplastic effects of $\beta$-carotene on colorectal adenoma recurrence: results of a randomized trial. J Natl Cancer Inst 95, 717-722.

16. Giovannucci E (1999) Tomatoes, tomato-based products, lycopene, and cancer: review of the epidemiologic literature. $J$ Natl Cancer Inst 91, 317-331.

17. Levy J, Bosin E, Feldman B, Giat Y, Miinster A, Danilenko M \& Sharoni Y (1995) Lycopene is a more potent inhibitor of human cancer cell proliferation than either $\alpha$-carotene or $\beta$-carotene. Nutr Cancer 24, 257-266.

18. Prakash P, Russell RM \& Krinsky NI (2001) In vitro inhibition of proliferation of estrogen-dependent and estrogen-independent human breast cancer cells treated with carotenoids or retinoids. J Nutr 131, 1574-1580.

19. Kotake-Nara E, Kushiro M, Zhang H, Sugawara T, Miyashita K \& Nagao A (2001) Carotenoids affect proliferation of human prostate cancer cells. J Nutr 131, 3303-3306.

20. De Kok TM \& van Maanen JM (2000) Evaluation of fecal mutagenicity and colorectal cancer risk. Mutat Res 463, 53-101.

21. Lapre JA \& Van der Meer R (1992) Diet-induced increase of colonic bile acids stimulates lytic activity of fecal water and proliferation of colonic cells. Carcinogenesis 13, 41-44.

22. Geltner-Allinger UG, Johansson GK, Gustafsson JA \& Rafter JJ (1989) Shift from a mixed to a lactovegetarian diet: influence on acidic lipids in fecal water - a potential risk factor for colon cancer. Am J Clin Nutr 50, 992-996.

23. Govers MJ, Termont DS, Lapre JA, Kleibeuker JH, Vonk RJ \& Van der MR (1996) Calcium in milk products precipitates intestinal fatty acids and secondary bile acids and thus inhibits colonic cytotoxicity in humans. Cancer Res 56, 3270-3275.

24. Glinghammar B, Venturi M, Rowland IR \& Rafter JJ (1997) Shift from a dairy product-rich to a dairy product-free diet: influence on cytotoxicity and genotoxicity of fecal water-potential risk factors for colon cancer. Am J Clin Nutr 66, $1277-1282$.

25. Müller H, Bub A, Watzl B \& Rechkemmer G (1999) Plasma concentrations of carotenoids in healthy volunteers after intervention with carotenoid-rich foods. Eur J Nutr 38, 35-44. 
26. Güldutuna S, You T, Kurts W \& Leuschner U (1993) High-performance liquid-chromatographic determination of free and conjugated bile-acids in serum, liver biopsies, bile, gastric-juice and faeces by fluorescence labeling. Clin Chim Acta 214, 195-207.

27. Hylla S, Gostner A, Dusel G, Anger H, Bartram HP, Christl SU, Kasper H \& Scheppach W (1998) Effects of resistant starch on the colon in healthy volunteers: possible implications for cancer prevention. Am J Clin Nutr 67, 136-142.

28. Franceschi S, Parpinel M, La Vecchia C, Favero A, Talamini R \& Negri E (1998) Role of different types of vegetables and fruit in the prevention of cancer of the colon, rectum, and breast. Epidemiology 9, 338-341.

29. Ax K, Schubert H, Briviba K, Rechkemmer G \& Tevini M (2001) Oil-in-water emulsions as carriers of bioavailable carotenoids. In Proceedings of the International Congress of Particle Technology, Nürnberg, Germany (CD-ROM) PARTEC, 4-B-153.

30. Faulks RM \& Southon S (2005) Challenges to understanding and measuring carotenoid bioavailability. Biochim Biophys Acta 1740, 95-100.

31. Goni I, Serrano J \& Saura-Calixto F (2006) Bioaccessibility of $\beta$-carotene, lutein and lycopene from fruits and vegetables. J Agric Food Chem 54, 5382-5387.

32. Haza AI, Glinghammar B, Grandien A \& Rafter J (2000) Effect of colonic luminal components on induction of apoptosis in human colonic cell lines. Nutr Cancer 36, 79-89.
33. Glinghammar B, Holmberg K \& Rafter J (1999) Effects of colonic lumenal components on AP-1-dependent gene transcription in cultured human colon carcinoma cells. Carcinogenesis 20, 969-976.

34. Latta RK, Fiander H, Ross NW, Simpson C \& Schneider H (1993) Toxicity of bile acids to colon cancer cell lines. Cancer Lett 70, 167-173.

35. Walker AR, Walker BF \& Walker AJ (1986) Faecal pH, dietary fibre intake, and proneness to colon cancer in four South African populations. Br J Cancer 53, 489-495.

36. Wächtershäuser A \& Stein J (2000) Rationale for the luminal provision of butyrate in intestinal diseases. Eur J Nutr 39, $164-171$.

37. Huycke MM \& Gaskins HR (2004) Commensal bacteria, redox stress, and colorectal cancer: mechanisms and models. Exp Biol Med (Maywood) 229, 586-597.

38. Bartram HP, Gostner A, Kelber E, Dusel G, Weimer A, Scheppach W \& Kasper H (1996) Effects of fish oil on fecal bacterial enzymes and steroid excretion in healthy volunteers: implications for colon cancer prevention. Nutr Cancer 25, 71-78.

39. Karlsson PC, Huss U, Jenner A, Halliwell B, Bohlin L \& Rafter JJ (2005) Human fecal water inhibits COX-2 in colonic HT-29 cells: role of phenolic compounds. J Nutr 135, 2343-2349. 